Article

\title{
Evaluation of Silica-Coated Insect Proof Nets for the Control of Aphis fabae, Sitophilus oryzae, and Tribolium confusum
}

\author{
Paraskevi Agrafioti ${ }^{1, *(1)}$, Sofia Faliagka ${ }^{2}$, Evagelia Lampiri ${ }^{1}$, Merle Orth ${ }^{3}$, Mark Pätzel ${ }^{3}$, \\ Nikolaos Katsoulas ${ }^{2}$ (D) and Christos G. Athanassiou ${ }^{1}$ (D) \\ 1 Laboratory of Entomology and Agricultural Zoology, Department of Agriculture, Crop Production and \\ Rural Environment, University of Thessaly, Phytokou str., 38446 Volos, Magnesia, Greece; \\ elampiri@agr.uth.gr (E.L.); athanassiou@agr.uth.gr (C.G.A.) \\ 2 Laboratory of Agricultural Constructions and Environmental Control, Department of Agriculture Crop \\ Production and Rural Environment, University of Thessaly, Phytokou Street, 38446 Volos Magnesia, Greece; \\ sofia.faliagka@gmail.com (S.F.); nkatsoul@uth.gr (N.K.) \\ 3 Institut für Textiltechnik der RWTH Aachen University, Otto-Blumenthal-St. 1, 52074 Aachen, Germany; \\ merle.orth1@gmail.com (M.O.); mark.paetzel@ita.rwth-aachen.de (M.P.) \\ * Correspondence: agrafiot@agr.uth.gr
}

Received: 13 July 2020; Accepted: 18 August 2020; Published: 24 August 2020

\begin{abstract}
Insect proof nets are widely used in agriculture as mechanical and physical barriers to regulate pest populations in a greenhouse. However, their integration in the greenhouse ventilation openings is highly associated with the decrease of air flow and the adequate ventilation. Thus, there is need for alternative pest management tools that do not impair adequate ventilation. In the present study, we tested four net formulations of relatively large mesh size coated with $\mathrm{SiO}_{2}$ nanoparticles, namely, ED3, ED3-P, ED5, and ED5-P to evaluate their insecticidal properties against adults of Aphis fabae and Sitophilus oryzae and larvae of Tribolium confusum. ED3 and ED5 nets were coated with $\mathrm{SiO}_{2}$ nanoparticles of different diameter, while in the case of ED3-P and ED5-P, paraffin was added to increase the mass of the deposited particles on the net's surface. In the first series of bioassays, the knockdown and mortality rates of these species were evaluated after exposure to the aforementioned net formulations for 5, 10, 15, 20, 25, 30, 60, 90, and $180 \mathrm{~min}$. In the second series of bioassays, knockdown and mortality of these species were recorded after 1, 7, and 10 days of post-exposure to the nets for different time intervals $(15,30$, and $60 \mathrm{~min})$. Based on our results, all nets significantly affected $A$. fabae, since all insects were dead at the 1-day post-exposure period to the silica-treated nets. Conversely, at the same interval, no effect on either S. oryzae adults or T. confusum larvae was observed. However, in the case of S. oryzae, the efficacy of all nets reached $100 \% 7$ days after the exposure, even for adults that had been initially exposed for $15 \mathrm{~min}$ to the treated nets. Among the species tested, T. confusum larvae exhibited the lowest mortality rate, which did not exceed $34 \%$ at the 10 days of post-exposure interval. Our work underlines the efficacy of treated nets in pest management programs, under different application scenarios, at the pre- and post-harvest stages of agricultural commodities.
\end{abstract}

Keywords: net formulations; stored product insects; knockdown; mortality; long-term effect

\section{Introduction}

Despite the association of many insecticidal compounds with mammalian toxicity and increased environmental footprint, conventional pesticides are widely used as a means of pest management. Over the years, many insects species have developed resistance mechanisms to the vast majority of 
active ingredients that are used as synthetic insecticides [1-3]. According to the European Commission, a sustainable and environmentally friendly insecticidal strategy should be followed in the case of adequate crop protection, to minimize the negative effects of the intensive chemical pesticide applications on both natural enemies (predators, parasitoids) and human health [4,5]. Thus, the notion of integrated pest management (IPM) has now become entrenched in agriculture.

Nets are widely used in agriculture as mechanical or physical barriers in order to protect crops from either biotic or abiotic stresses. In the Mediterranean region, protection against insects is considered significantly important even compared to the management of excessive heat during the summer [6]. Insect proof nets have been integrated in greenhouse ventilation openings as an alternative to pesticides for many years and their use is related to the management of the population density of external agents. At the same time, exclusion nets are used to cover entire greenhouse structures or screenhouses [7]. Nets have a dual effect as they block the penetration of pests, while prevent the escape of insects used for crop pollination [8]. The design of nettings is determined by the size and geometry of the hole, the size of the insect thorax, as well as the method of knitting [9].

According to Kittas et al. [6], the environment of a greenhouse is qualified by significant heterogeneity in which various factors contribute, such as the crop itself, the cover materials and the insect screens. Microclimate conditions of a greenhouse are strongly affected by nets' physical and optical properties [10]. Very fine mesh size nets severely affect the ventilation and air capacity of the enclosed area by decreasing permeability [11,12]. Indeed, the ventilation rate can be decreased by $40-50 \%$ when anti-aphid or anti-thrip nettings are applied $[11,13]$. These results are in accordance with those of Katsoulas et al. [14], who indicated a 33\% decrease of ventilation flow due to the installation of an anti-aphid insect screen with $50 \%$ porosity on the vents of a polyethylene-covered greenhouse. In addition, Baeza et al. [15] showed that the use of an anti-insect screen with porosity of $25 \%$, which is commonly used to exclude white flies Bemisia tabaci (Gennadius) (Hemiptera: Aleyrodoidae) and the western flower thrips Frankliniella occidentalis (Pergande) (Thysanoptera: Thripidae), could lead to a ventilation reduction of approximately $88 \%$. As a result, higher temperature regimes are recorded in the interior of the protected greenhouse plants leading to non-uniform production, increased yield losses, as well as quality deterioration [6,14]. Small mesh size nets (i.e., low porosity nets) may contribute to undesired results, since they exclude not only harmful pests but also beneficial insects [16]. Moreover, Bell and Baker [11], showed that the migration of insects in a greenhouse is not always correlated to the mesh size, since insects with very small thoracic width, such as whiteflies, can intrude the finest pore size net.

The establishment of insect proof nets for the stored product pest management is directly linked to environmental protection, as their use does not lead to residues or to contamination in storage facilities and stored commodities [17]. Many studies are focused on the design of long-lasting insecticidetreated nets (LLINs) by incorporating insecticides into the net coating in order to minimize the chemical sprays directly on the crop [18,19]. Dáder et al. [18] showed that LLINs caused a significant reduction in Myzus persicae (Sulzer) (Hemipetra: Aphidedae) and Aphis gossypii (Glover) (Hemipetra: Aphididae) immigration without affecting the parasitoid Aphidius colemani Viereck (Hymenoptrea: Aphididae). However, during field trials, LLINs effectiveness was degraded after sun exposure whereas, the efficacy of either bifenthrin or deltamethrin was suggested as insufficient to control $B$. tabaci culture due to its small size. Notwithstanding, according to Arthurs et al. [19], nettings of large mesh size treated with deltamethrin proved insufficient to protect a greenhouse crop from F. occidentalis invasion. Hence, both the effect of LLINs on beneficial enemies and their effectiveness in small sized insects should be further evaluated [18].

Recently, Rumbos et al. [17] successfully demonstrated the efficacy of Carifend ${ }^{\circledR}$, a polyester net coated with alpha-cypermethrin, against two stored tobacco insect pests, the cigarette beetle, Lasioderma serricorne (F.) (Coleoptera: Anobiidae) and the tobacco moth, Ephestia elutella (Hübner) (Lepidoptera: Pyralidae). Moreover, Paloukas et al. [20] suggested that Carifend ${ }^{\circledR}$ could be effectively used to 
control different major stored-product insects such as the rice weevil, Sitophilus oryzae (L.) (Coleoptera: Curculionidae), since $98 \%$ mortality was recorded two weeks after the exposure to the treated net.

The use of nanoparticles as a novel biological insect control agent has been well established in the recent years. Silicon is known as the most frequent metalloid and the most copious element on earth after oxygen [21-23]. The mode of action of silicon dioxide $\left(\mathrm{SiO}_{2}\right)$ begins with the adherence of the nanoparticles on the cuticle of the insect, inactivating epicuticular lipids, which leads to death through desiccation [24,25]. Furthermore, Rastogi et al. [22], suggested that the mortality of pests could be related to congestion of spiracles and tracheas caused by the nanosilica particles.

Diatomaceous earth (DE) that consists mainly of amorphous hydrated silica has been extensively used in stored product insect management. Vayias and Athanassiou [26] stated that the effectiveness of DE is associated with the developmental stage of the insects. Indeed, the management of the confused flour beetle adults, Tribolium confusum Jacquelin DuVal (Coleoptera: Tenebrionidae) is considerably difficult compared to soft-bodied greenhouse pests such as aphids. On the other hand, aphids are among the most common pests in horticultural crops and are related to the transmission of many economically hazardous viruses even after injecting their sucking mouthparts on the leaves for a very short time interval $[18,27]$. Unlike hard-bodied beetles, aphids are considered to be much more vulnerable to desiccation from sorptive materials and micro-wounds. For instance, Singh and Singh [28] found that DEs could cause rapid mortality of the aphid Rhopalosiphum padi (L.) (Homoptera: Aphididae), when applied on wheat plants. However, in that study, the authors stood eventually against these DE applications, because of negative photosynthetic rates [28].

Recently, Shoaib et al. [29], indicated that the exposure of larvae of Plutella xylostella (L.) (Lepidoptera: Plutellidae) to $1 \mathrm{mg} \times \mathrm{cm}^{-2}$ of a siliceous dust formulation resulted in $85 \%$ mortality after $72 \mathrm{~h}$. The authors suggested that the mortality rate is improved as dose and exposure interval are increased. Moreover, silica nanoparticles, concerning their physical and chemical properties, differ significantly from their bulk formation [19]. According to Debnath et al. [30], nanoparticles proved to be much more effective when compared with bulk silica against $S$. oryzae. At the post-harvest stages of agricultural commodities, stored product protection could be enhanced by the use of silicon-based nanoparticles as non-conventional pesticide agents [2,31].

To date, little attention has been given to the incorporation of physical inert dusts to the yarns of insect proof nets. The application of non-toxic and environmental-friendly nets could replace the insecticidal treated nets leading to insecticide-free products. Thus, the objective of our study was to assess the effectiveness of silicon dioxide-treated nets under laboratory conditions for the control of the black bean aphid, Aphis fabae Scopoli (Hemipetra: Aphididae), and the stored product pests T. confusum and S. oryzae. The aforementioned species were exposed to insect proof nets coated with two different silicon dioxide dust formulations, Syloid ${ }^{\circledR}$ ED3 and Syloid ${ }^{\circledR}$ ED5 with and without the addition of paraffin in order to achieve better particle adherence to the net, respectively.

\section{Materials and Methods}

\subsection{Insects Tested}

The rearing of the A. fabae individuals took place at the Laboratory of Agricultural Entomology, Benaki Phytopathological Institute, Attica, Greece. Aphids were reared on Vicia faba L. plants at $20 \pm 1{ }^{\circ} \mathrm{C}$, relative humidity (r.h.) of $65 \pm 2 \%$ and a photoperiod of $16 \mathrm{~h}$ in light: $8 \mathrm{~h}$ in dark [32]. Aphid colonies were transferred to the Laboratory of Entomology and Agricultural Zoology (LEAZ), Department of Agriculture, Crop Production and Rural Environment, University of Thessaly to carry out the bioassays.

Established laboratory colonies of S. oryzae and T. confusum were maintained in LEAZ under controlled conditions in a growth chamber as suggested by Faliagka et al. [33]. 


\subsection{Nettings and Dust Formulations}

Experiments were carried out with four samples of the same insect proof net, the textiles of which were performed by the Institut für Textiltechnik (ITA) of RWTH Aachen University. The weaving and the evaluation of the nets was provided from Thrace Nonwovens \& Geosynthetics S.A. (Thrace, Greece). All textiles were coated either with Syloid ${ }^{\circledR}$ ED3 or Syloid ${ }^{\circledR}$ ED5 which are amorphous silica dust formulations (P\&S Powder and Surface GmbH, Salzkotten, Germany). The former silica dust consists of $99-100 \% \mathrm{SiO}_{2}$ with particle size of $5.8 \mu \mathrm{m}$, while the latter consists of $95-100 \% \mathrm{SiO}_{2}$ with particle size of $9.0 \mu \mathrm{m}$. Paraffin was added as an organic primer in two of the four netting samples (ED3-P and ED5-P) consisting of different silica formulation in order to enhance the adhesion properties of each dust to the net. ED3 and ED5 samples were used without the addition of paraffin. The purpose of the primer is the integration of up to $40 \%$ more $\mathrm{SiO}_{2}$ particles on the net. The mass of the deposited silica particles on the net's surface was fluctuated from 0.4 to $0.9 \mathrm{~g} \times \mathrm{m}^{-2}$ depending on the dust formulation as well as the addition of paraffin. However, paraffin may reduce the mesh size and therefore, the air permeability properties of the tested nets. In the present study, the insecticidal properties of $\mathrm{SiO}_{2}$ nanoparticles were evaluated. In the case where adequate results are provided, it is suggested to incorporate silica on nets of larger pores in order to alleviate insufficient ventilation. Table 1 shows the properties of the nets used in the experimental trials.

Table 1. Properties of the silicon coated nets ED3 (without paraffin), ED3-P (paraffin), ED5 (without paraffin), and ED5-P (paraffin).

\begin{tabular}{ccccc}
\hline Sample & Mesh Size & $\begin{array}{c}\text { Silica Particles } \\
\text { Diameter }(\mu \mathrm{m})\end{array}$ & $\begin{array}{c}\text { Coating } \\
\text { Repetition }\end{array}$ & $\begin{array}{c}\text { Mass of Deposited Silica } \\
\text { Particles on the Surface } \\
\text { of the Net }\left(\mathbf{g}^{-2} \mathbf{~ m}^{-2}\right)\end{array}$ \\
\hline ED3 & 50 mesh & 5.8 & 2 & 0.4 \\
ED3-P & 50 mesh & 5.8 & 2 & 0.7 \\
ED5 & 50 mesh & 9.0 & 2 & 0.7 \\
ED5-P & 50 mesh & 9.0 & 2 & 0.9 \\
\hline
\end{tabular}

All samples were produced by the same 50 mesh net that was constructed by using high density polyethylene (HDPE) monofilament yarns. $\mathrm{SiO}_{2}$ free-nettings with the same mesh size as well as clear Petri dishes without the addition of nets were used as a control treatment. The silica coating procedure was repeated two times for each tested net.

\subsection{Bioassay Series}

Nets were fine cut and adjusted at the bottom of plastic Petri dishes (59.4 $\mathrm{cm}^{2}$ in surface), using a thin layer of silicon. The lids of plastic dishes are usually loose-fitting making it easy for insects to escape, so, the "neck" of each Petri dish was covered with polytetrafluoroethylene dispersion, (Northern Product, Cumberland, RI, USA). A single fine brush was used to insert the species into the Petri dishes to avoid wounding.

\subsubsection{Short-Term Effect}

In the short-term effect bioassay series, adults of A. fabae and S. oryzae, and larvae of T. confusum were used. Ten insects of each species were transferred to the Petri dishes. All species were exposed to silica-treated nets, clear Petri dishes (without nets), and untreated nets for the intervals of 5, 10, 15, 20, 25, 30, 60, 90, and 180 min. For each exposure interval, mortality and knockdown effect of all species in each Petri dish were recorded. For each of the four nets, the bioassay was replicated eight times per exposure interval. Thus, in this series of bioassays 144 Petri dishes were used in total. 


\subsubsection{Long-Term Effect}

The purpose of this series of bioassays was to evaluate the effect of the nets on the knockdown and mortality rates of the exposed individuals at certain post-exposure intervals. Thus, as above, ten individuals of each species were transferred to Petri dishes, with different plates per species, and exposed to the nets for 15, 30, and $60 \mathrm{~min}$. Knockdown and mortality were recorded immediately after the completion of the exposure periods and then all insects were carefully transferred to new dishes consisting of untreated nets or clear Petri dishes (without nets). When transferring the insects, a clean single fine brush was used to avoid possible contamination of the dust in the treated nets. Within each exposure interval of 15, 30, and $60 \mathrm{~min}$ no food was added in the Petri dishes. However, during post-exposure period for $S$. oryzae and T. confusum, cracked wheat $(0.5 \pm 0.1 \mathrm{gr})$ and wheat flour $(1.0 \pm 0.1 \mathrm{gr})$ were added in all petri dishes, respectively. In the case of $A$. fabae no food was supplied, since the bioassay lasted one day, unlike that of the stored product insects which was completed after 10 days. All bioassays were carried out at $25{ }^{\circ} \mathrm{C}$ and $65 \%$ r.h. Mortality and knockdown effect of S. oryzae and T. confusum were assessed after 1, 7, and 10 days, whereas in the case of $A$. fabae after 1 day. For each of the four nets, the bioassays were replicated eight times. A total of 624 Petri dishes were used to perform this series of bioassays.

\subsection{Statistical Analysis}

The results of the first series of bioassay (short-term effect) were analyzed using Probit Analysis to estimate the knockdown time, i.e., $\mathrm{KD}_{\mathrm{t} 50}, \mathrm{KD}_{\mathrm{t} 95}$, and $\mathrm{KD}_{\mathrm{t} 99}$ for each species and net formulation. The intervals tested yielded a variety of knockdown results only for $A$. fabae, which allowed the calculation of $\mathrm{KD}_{\mathrm{t} 50}, \mathrm{KD}_{\mathrm{t} 95}$, and $\mathrm{KD}_{\mathrm{t} 99}$ values. For the second series of bioassays, separately of each species, the data (knockdown and mortality) were converted to percentages and then were submitted to a two-way ANOVA, to determine the differences among the exposure intervals (15, 30, and $60 \mathrm{~min})$ and among the net formulations (including controls as well), while means of knockdown and mortality were separated using the Tukey-Kramer HSD test at the 5\% level. Moreover, the same approach was conducted for the long-term effect for each species tested. The data were analyzed using SPSS 25.0 (SPSS Inc., Chicago, IL, USA).

\section{Results}

\subsection{Short-Term Effect}

The mortality rate of all tested species was relatively low. In the first series of tests, $K \mathrm{D}_{\mathrm{t}}$ values were not found to fit the data well, since $P$ values were $<0.01$ (Table 2). In most of the cases, confidence interval could not be estimated for A. fabae and S. oryzae, except for ED5-P of A. fabae. For T. confusum, Probit could not be estimated, since the percentage of knocked down individuals was negligible (data not presented).

Overall, $\mathrm{KD}_{\mathrm{t} 99}$ values for $A$. fabae at ED3-P resulted in the highest values among treatments, corresponding to $1590.9 \mathrm{~min}$ (approximately $26 \mathrm{~h}$ ) (Table 2). Contrariwise, the lowest $\mathrm{KD}_{\mathrm{t} 99}$ value was recorded at ED5-P, corresponding to $363.3 \mathrm{~min}$ (approximately $6 \mathrm{~h}$ ) (Table 2). Moreover, for S. oryzae the resulting values were similar with those of $A$. fabae at ED3, which were $1235.7 \mathrm{~min}$ (approximately $20 \mathrm{~h}$ ) and $1281.4 \mathrm{~min}$ (approximately $21 \mathrm{~h}$ ), respectively. For $\mathrm{KD}_{\mathrm{t} 50}$ the lowest value $(51.3 \mathrm{~min}$ ) for A. fabae was recorded at ED5, whereas the highest value (279.7 $\mathrm{min}$ ) was noted at ED3-P (Table 2). 
Table 2. Probit analysis for $\mathrm{KD}_{\mathrm{t} 50}, \mathrm{KD}_{\mathrm{t} 95}$, and $\mathrm{KD}_{\mathrm{T} 99}$ (confidence intervals) of Aphis fabae and Sitophilus oryzae adults exposed to four different nets (ED3, ED3-P, ED5, ED5-P) for $180 \mathrm{~min}$, values are expressed as minutes to knockdown.

\begin{tabular}{|c|c|c|c|c|c|c|c|}
\hline$\#$ & Nets & $\mathrm{KD}_{\mathrm{t} 50}$ & $\mathrm{KD}_{\mathrm{t} 95}$ & $\mathrm{KD}_{\mathrm{t} 99}$ & Slope \pm SE & $\mathrm{X}^{2}$ & $P$ \\
\hline \multirow{3}{*}{ A. fabae } & ED3 & $253.3^{a}$ & $980.2^{a}$ & $1281.4^{\mathrm{a}}$ & $2.7 \pm 0.1$ & 389.8 & $<0.01$ \\
\hline & ED3-P & $279.7^{\mathrm{a}}$ & $1206.8^{a}$ & $1590.9^{a}$ & $2.1 \pm 0.1$ & 290.9 & $<0.01$ \\
\hline & ED5-P & $\begin{array}{c}74.9 \\
(49.8-109.1)\end{array}$ & $\begin{array}{c}278.8 \\
(206.6-465.8)\end{array}$ & $\begin{array}{c}363.3 \\
(265.6-619.5)\end{array}$ & $9.6 \pm 0.1$ & 372.8 & $<0.01$ \\
\hline$\#$ & Nets & $K D_{t 50}$ & $K_{\mathbf{t}_{95}}$ & $K_{\text {t99 }}$ & Slope $\pm S E$ & $\mathrm{X}^{2}$ & $P$ \\
\hline \multirow{3}{*}{ S. oryzae } & ED3-P & $767.3^{a}$ & $1098.5^{a}$ & $1235.7^{a}$ & $0.6 \pm 0.1$ & 449.7 & $<0.01$ \\
\hline & ED5 & - & - & - & - & - & - \\
\hline & ED5-P & - & - & - & - & - & - \\
\hline
\end{tabular}

${ }^{a}$ Could not estimate confidence intervals; - Could not estimate knockdown time.

\subsection{Long-Term Effect}

The mortality rate ranged significantly between the tested cases (Tables $3-5$ ). Knockdown of $A$. fabae was low and did not exceed $28.7 \%$ (Table 3), whereas mortality was negligible (data not presented). For knocked down individuals, significant differences were noted in all tested net formulations among the time intervals $(15,30$, and $60 \mathrm{~min})$. Finally, at the 1-day post-exposure period, mortality was $100 \%$ in all tested net formulations (Table 3 ).

Regarding S. oryzae individuals, knockdown and mortality were negligible, in all tested net formulations for the 15, 30, and $60 \mathrm{~min}$ intervals (data not presented), while at the 1-day post-exposure period, no significant differences were noted among the exposure intervals (Table 4). At this interval, mortality was generally low, reaching $6.2 \%$. However, in most of the cases, at the 7-day post-exposure period mortality was approximately $87 \%$, even when the initial exposure was $15 \mathrm{~min}$, while after 10 days mortality reached $100 \%$ (Table 4 ).

Regarding T. confusum larvae, knockdown and mortality were generally low $(<5 \%$, data not presented). Larval knockdown of T. confusum was also negligible (data not presented). After $7 \mathrm{~d}$ of exposure in all formulations, mortality did not exceed $30 \%$, whereas after $10 \mathrm{~d}$ the highest mortality level was 34\% at ED5-P (Table 5). Significant differences were recorded among the exposure intervals in most of the cases (Table 5). 
Table 3. Short- and long-term knockdown (KD) and mortality ( $\% \pm$ SE) of Aphis fabae adults exposed for 15, 30, and 60 min to dishes with four different treated nets (ED3, ED3-P, ED5, ED5-P), dishes with untreated net and dishes without net. The first day after exposure for each exposure interval is considered as the long-term effect.

\begin{tabular}{|c|c|c|c|c|c|c|c|c|c|c|c|c|c|c|c|c|c|c|}
\hline \multirow[b]{3}{*}{$\begin{array}{c}\text { Exposure } \\
\text { time }\end{array}$} & \multicolumn{3}{|c|}{ ED3 } & \multicolumn{3}{|c|}{ ED3-P } & \multicolumn{3}{|c|}{ ED5 } & \multicolumn{3}{|c|}{ ED5-P } & \multicolumn{3}{|c|}{ Untreated net } & \multicolumn{3}{|c|}{ Without net } \\
\hline & \multirow{2}{*}{$\begin{array}{c}\text { Short term } \\
\text { KD }\end{array}$} & \multicolumn{2}{|c|}{ Long term } & \multirow{2}{*}{$\begin{array}{c}\text { Short term } \\
\text { KD }\end{array}$} & \multicolumn{2}{|c|}{ Long term } & \multirow{2}{*}{$\begin{array}{c}\text { Short term } \\
\text { KD } \\
\end{array}$} & \multicolumn{2}{|c|}{ Long term } & \multirow{2}{*}{$\begin{array}{c}\text { Short term } \\
\text { KD }\end{array}$} & \multicolumn{2}{|c|}{ Long term } & \multirow{2}{*}{$\begin{array}{c}\text { Short term } \\
\text { KD } \\
\end{array}$} & \multicolumn{2}{|c|}{ Long term } & \multirow{2}{*}{$\begin{array}{c}\text { Short term } \\
\text { KD } \\
\end{array}$} & \multicolumn{2}{|c|}{ Long term } \\
\hline & & KD & Mortality & & KD & Mortality & & KD & Mortality & & KD & Mortality & & KD & Mortality & & KD & Mortality \\
\hline $15 \mathrm{~min}$ & $0.0 \pm 0.0 \mathrm{a}$ & $0.0 \pm 0.0 \mathrm{~A}$ & $100.0 \pm 0.0 \mathrm{~A}$ & $0.0 \pm 0.0 \mathrm{a}$ & $0.0 \pm 0.0 \mathrm{~A}$ & $100.0 \pm 0.0 \mathrm{~A}$ & $0.0 \pm 0.0 \mathrm{a}$ & $0.0 \pm 0.0 \mathrm{~A}$ & $100.0 \pm 0.0 \mathrm{~A}$ & $0.0 \pm 0.0 \mathrm{a}$ & $0.0 \pm 0.0 \mathrm{~A}$ & $100.0 \pm 0.0 \mathrm{~A}$ & $0.0 \pm 0.0$ & $2.5 \pm 2.5 \mathrm{~A}$ & $100.0 \pm 0.0 \mathrm{~A}$ & $\begin{array}{l}0.0 \pm 0.0 \\
0.0+0 .\end{array}$ & $\begin{array}{r}20.0 \pm 3.2 \mathrm{~B} \\
225+13 \mathrm{~B}\end{array}$ & $36.2 \pm 8.6 \mathrm{~B}$ \\
\hline $30 \mathrm{~min}$ & $0.0 \pm 0.0 \mathrm{a}$ & $0.0 \pm 0.0 \mathrm{~A}$ & $100.0 \pm 0.0 \mathrm{~A}$ & $\begin{array}{l}0.0 \pm 0.0 \mathrm{a} \\
2.5 \pm 31\end{array}$ & $0.0 \pm 0.0 \mathrm{~A}$ & $100.0 \pm 0.0 \mathrm{~A}$ & $\begin{array}{c}0.0 \pm 0.0 \mathrm{a} \\
287+39 \mathrm{bA}\end{array}$ & $0.0 \pm 0.0 \mathrm{~A}$ & $100.0 \pm 0.0 \mathrm{~A}$ & $\begin{array}{r}0.0 \pm 0.0 \mathrm{a} \\
150 \pm 46 \mathrm{ba}\end{array}$ & $0.0 \pm 0.0 \mathrm{~A}$ & $100.0 \pm 0.0 \mathrm{~A}$ & $\begin{array}{l}0.0 \pm 0.0 \\
0.00 \mathrm{~B}\end{array}$ & $\begin{array}{l}0.0 \pm 0.0 \mathrm{~A} \\
0.0 \pm 0 \mathrm{~A}\end{array}$ & $\begin{array}{l}100.0 \pm 0.0 \mathrm{~A} \\
93.7 \pm 4.1 \mathrm{~A}\end{array}$ & $\begin{array}{l}0.0 \pm 0.0 \\
0.0 \pm 0.0 \mathrm{~B}\end{array}$ & $\begin{array}{l}22.5 \pm 13.1 \mathrm{~B} \\
16.2 \pm 4.6 \mathrm{~B}\end{array}$ & $\begin{array}{l}12.5 \pm 3.1 \mathrm{~B} \\
22.7 \pm 6.7 \mathrm{~B}\end{array}$ \\
\hline $\begin{array}{l}60 \min _{\mathrm{F}} \\
\end{array}$ & $\begin{array}{l}27.5 \pm 4.5 \mathrm{bA} \\
36.8\end{array}$ & $0.0 \pm 0.0 \mathrm{~A}$ & $100.0 \pm 0.0 \mathrm{~A}$ & $\begin{array}{l}22.5 \pm 3.1 .1 \mathrm{bA} \\
51.5\end{array}$ & $0.0 \pm 0.0 \mathrm{~A}$ & $100.0 \pm 0.0 \mathrm{~A}$ & $\begin{array}{l}28.7 \pm 3.9 \mathrm{bA} \\
52.1\end{array}$ & $0.0 \pm 0.0 \mathrm{~A}$ & $100.0 \pm 0.0 \mathrm{~A}$ & $\begin{array}{l}15.0 \pm 4.6 \mathrm{bA} \\
10.5\end{array}$ & $0.0 \pm 0.0 \mathrm{~A}$ & $1000.0 \pm 0.0 \mathrm{~A}$ & $0.0 \pm 0.0 \mathrm{~B}$ & $\begin{array}{l}0.0 \pm 0.0 \mathrm{~A} \\
1.0\end{array}$ & $\begin{array}{l}93.7 \pm 4.1 \mathrm{~A} \\
2.2\end{array}$ & $0.0 \pm 0.0 \mathrm{~B}$ & 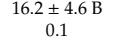 & $\begin{array}{l}23.7 \pm 6.7 \mathrm{~B} \\
3.2\end{array}$ \\
\hline${ }_{P}$ & $\begin{array}{l}20.8 \\
<0.01\end{array}$ & - & - & $\begin{array}{l}3.5 \\
<0.01\end{array}$ & & - & $\begin{array}{l}2.1 \\
<0.01\end{array}$ & & - & $\begin{array}{l}11.3 \\
<0.01\end{array}$ & - & & - & $\begin{array}{l}1.0 \\
0.38\end{array}$ & 0.13 & - & 0.86 & $\begin{array}{l}3.2 \\
0.06\end{array}$ \\
\hline
\end{tabular}

Within each exposure interval, post-exposure interval, and net formulation, means followed by the same lowercase letters (a, b) do not differ significantly according to Tukey-Kramer HSD test at $P<0.05$. Within each exposure interval, post-exposure interval, and net formulation, mortality, and knockdown means followed by the same uppercase letters (A, B) do not differ significantly across treatments according to Tukey-Kramer HSD test at $P<0.05$. Where no letter exist, no significant differences were noted. ANOVA parameters for long-term effect and knocked down adults were: at $15 \mathrm{~min} F=22.8, P<0.01,30 \mathrm{~min}, \mathrm{~F}=2.9, P=0.02,60 \mathrm{~min}, \mathrm{~F}=12.4, P<0.01$, whereas for short-term effect and knocked down adults at 60 min, $\mathrm{F}=22.9, P<$ 0.01 . For delayed mortality at $15 \mathrm{~min}, \mathrm{~F}=54.3, P<0.01,30 \mathrm{~min}, \mathrm{~F}=779.5, P<0.01,60 \mathrm{~min}, \mathrm{~F}=88.7, P<0.01$, in all cases $d f=2,23$. In the case where "-"is indicated, $\mathrm{F}$ and $P$ values were not provided in the Table since no variances among the samples were recorded.

Table 4. Delayed mortality (\% \pm SE) of Sitophilus oryzae adults exposed for 15, 30, and 60 min to dishes with four different nets (ED3, ED3-P, ED5, ED5-P), dishes with untreated net and dishes without net. The 1st, 7th and 10th day after exposure for each exposure interval is considered as the long-term effect.

\begin{tabular}{|c|c|c|c|c|c|c|c|c|c|c|c|c|c|c|c|c|c|c|}
\hline \multirow[b]{2}{*}{$\begin{array}{l}\text { Exposurur } \\
\text { time (d) }\end{array}$} & \multicolumn{3}{|c|}{ ED3 } & \multicolumn{3}{|c|}{ ED3-P } & \multicolumn{3}{|c|}{ ED5 } & \multicolumn{3}{|c|}{ ED5-P } & \multicolumn{3}{|c|}{ Untreated Net } & \multicolumn{3}{|c|}{ Without Net } \\
\hline & 1st & 7th & 10th & 1st & 7th & 10th & 1st & 7th & 10th & 1st & 7th & 10th & 1st & 7th & 10th & 1st & 7th & 10th \\
\hline $15 \min$ & .6 & $100.0 \pm 0.0 \mathrm{~A}$ & 1 & 0 & $97.5 \pm 2$ & $98.7 \pm 1$ & \pm 0.0 & $100.0 \pm 0.0 \mathrm{aA}$ & $100.0 \pm 0$. & \pm 1.8 & $100.0 \pm 0.0 \mathrm{bA}$ & $100.0 \pm 0$ & $6.2 \pm 4.1$ & B & $56.2 \pm 9$ & $0.0 \pm 0.0$ & $0.0 \mathrm{C}$ & $2 \pm 2.2 \mathrm{C}$ \\
\hline 30 & 8 & $\pm 2.5 \mathrm{~A}$ & 1 & & 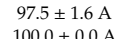 & & $00+0$ & & & & $\begin{array}{l}97.5 \pm 2.5 \mathrm{abA} \\
875+52 .\end{array}$ & & & & & $\begin{array}{l}0.0 \pm 0.0 \\
0.0 \pm 0.0\end{array}$ & $\begin{array}{l}0.0 \pm 0.0 \mathrm{C} \\
0.0 \pm 0.0 \mathrm{C}\end{array}$ & $\begin{array}{l}11.2 \pm 2.9 \mathrm{C} \\
125+3.1 \mathrm{C}\end{array}$ \\
\hline $60 \min$ & $\begin{array}{l}2.5 \pm 1.6 \\
0.8\end{array}$ & $\begin{array}{c}98.7 \pm 1.2 \mathrm{~A} \\
0.6\end{array}$ & $100.0 \pm 0.0 \mathrm{~A}$ & $\begin{array}{c}3.7 \pm 1.8 \\
2.9\end{array}$ & 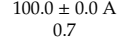 & $\begin{array}{c}100.0 \pm 0.0 \mathrm{~A} \\
1.0\end{array}$ & $0.0 \pm 0.0$ & $\begin{array}{c}100.0 \pm 0.0 \mathrm{aA} \\
4.2\end{array}$ & $\begin{array}{c}100.0 \pm 0.0 \mathrm{aA} \\
4.2\end{array}$ & $\begin{array}{l}0.0 \pm 0.0 \\
1.9\end{array}$ & $\begin{array}{l}87.5 \pm 5.2 \mathrm{aA} \\
3.9\end{array}$ & $\begin{array}{c}88.7 \pm 5.4 \mathrm{bA} \\
4.2\end{array}$ & $\begin{array}{l}2.5 \pm 2.5 \\
0.5\end{array}$ & $\begin{array}{l}43.7 \pm 9.9 \mathrm{~B} \\
1.3\end{array}$ & $\begin{array}{l}56.2 \pm 9.8 \mathrm{~B} \\
2.3\end{array}$ & $0.0 \pm 0.0$ & $0.0 \pm 0.0 \mathrm{C}$ & $\begin{array}{c}12.5 \pm 3.1 \mathrm{C} \\
0.1\end{array}$ \\
\hline$P$ & $\begin{array}{l}.8 .83 \\
0.83\end{array}$ & $\begin{array}{l}0.6 \\
0.55\end{array}$ & & 0.07 & 0.50 & 0.38 & & 0.02 & 0.02 & 0.16 & 0.03 & 0.02 & 0.59 & 0.27 & 0.12 & - & - & $\begin{array}{l}0.1 \\
0.93\end{array}$ \\
\hline
\end{tabular}

Within each exposure interval, post-exposure interval, and net formulation, means followed by the same lowercase letters (a, b) do not differ significantly according to the Tukey-Kramer HSD test at $P<0.05$. Within each exposure interval, post-exposure interval, and net formulation, mortality means followed by the same uppercase letters (A, B) do not differ significantly across treatments according to the Tukey-Kramer HSD test at $P<0.05$. Where no letters exist, no significant differences were noted. ANOVA parameters for 1 st day were: at 15 min, $\mathrm{F}=1.9$, $P=0.10,30 \mathrm{~min}, \mathrm{~F}=1.6, P=0.18,60 \mathrm{~min}, \mathrm{~F}=1.3, P=0.26$, for 7 th day were: at $15 \mathrm{~min}, \mathrm{~F}=142.2, P<0.01,30 \mathrm{~min}, \mathrm{~F}=91.9, P<0.01,60 \mathrm{~min}, \mathrm{~F}=79.1, P<0.01$, whereas for 10 th day were: at $15 \mathrm{~min}, \mathrm{~F}=92.2, P<0.01,30 \mathrm{~min}, \mathrm{~F}=75.4, P<0.01,60 \mathrm{~min}, \mathrm{~F}=55.6, P<0.01$, in all cases $d f=5$, 47 . In the case where "- "is indicated, $\mathrm{F}$ and $P$ values were not provided in the Table since no variances among the samples were recorded. 
Table 5. Delayed mortality ( $\% \pm$ SE) of Tribolium confusum larvae exposed for 15, 30, and 60 min to dishes with four different nets (ED3, ED3-P, ED5, ED5-P), dishes with untreated net and dishes without net. The 1st, 7th, and 10th day after exposure for each exposure interval is considered as the long-term effect.

\begin{tabular}{|c|c|c|c|c|c|c|c|c|c|c|c|c|c|c|c|c|c|c|}
\hline \multirow[b]{2}{*}{$\begin{array}{l}\text { Exposure } \\
\text { time (d) }\end{array}$} & \multicolumn{3}{|c|}{ ED3 } & \multicolumn{3}{|c|}{ ED3-P } & \multicolumn{3}{|c|}{ ED5 } & \multicolumn{3}{|c|}{ ED5-P } & \multicolumn{3}{|c|}{ Untreated net } & \multicolumn{3}{|c|}{ Without Net } \\
\hline & 1st & 7th & 10th & 1 st & 7th & 10th & 1st & 7th & 10th & $1 \mathrm{st}$ & 7 th & 10th & 1st & 7th & 10th & 1st & 7th & 10th \\
\hline $\begin{array}{l}15 \min \\
30 \mathrm{~min}\end{array}$ & $\begin{array}{l}3.7 \pm 2.6 \\
0.0+00\end{array}$ & $\begin{array}{l}12.5 \pm 3.1 \mathrm{ab} \\
7.5 \pm 2.5 \mathrm{aA}\end{array}$ & $\begin{array}{l}13.7 \pm 3.2 \\
135+36\end{array}$ & $\begin{array}{c}1.2 \pm 1.2 \mathrm{a} \\
25 \pm 1.6 \mathrm{ab}\end{array}$ & $\begin{array}{c}8.7 \pm 4.4 \mathrm{a} \\
187 \pm 3.5 \mathrm{abB}\end{array}$ & $\begin{array}{l}18.7 \pm 3.5 \\
200+337\end{array}$ & $\begin{array}{l}2.5 \pm 1.6 \mathrm{ab} \\
00 \pm 00 \mathrm{a}\end{array}$ & $\begin{array}{r}13.7 \pm 4.1 \\
62 \pm 26 \mathrm{~A}\end{array}$ & $\begin{array}{l}28.7 \pm 2.9 \mathrm{a} \\
87+2 \mathrm{~b}\end{array}$ & $\begin{array}{l}2.5 \pm 1.6 \\
0.0 \pm 0.0\end{array}$ & $11.2 \pm 4.7 \mathrm{ab}$ & $\begin{array}{l}18.7 \pm 5.4 \mathrm{ab} \\
112+12 \mathrm{a}\end{array}$ & $\begin{array}{l}6.2 \pm 2.6 \\
25+2.5\end{array}$ & $\begin{array}{r}5.0 \pm 1.8 \\
75+25 A\end{array}$ & $16.2 \pm 3.7$ & $0.0 \pm 0.0$ & $3.7 \pm 2.6$ & $28.7 \pm 5.1$ \\
\hline $\begin{array}{l}30 \mathrm{~min} \\
60 \min \end{array}$ & $\begin{array}{c}0.0 \pm 0.0 \\
6.2 \pm 1.8 \mathrm{~B} \\
2.9\end{array}$ & $\begin{array}{c}7.5 \pm 2.5 \mathrm{aA} \\
20.0 \pm 4.2 \mathrm{bAB} \\
35\end{array}$ & $\begin{array}{r}12.5 \pm 3.6 \\
22.5 \pm 3.6 \\
24.6\end{array}$ & $\begin{array}{l}2.5 \pm 1.6 \mathrm{ab} \\
7.5 \pm 1.6 \mathrm{bB} \\
47\end{array}$ & $\begin{array}{l}18.7 \pm 3.5 \mathrm{abB} \\
30.0 \pm 5.3 \mathrm{bB}\end{array}$ & $\begin{array}{l}20.0 \pm 3.7 \\
32.5 \pm 5.2\end{array}$ & $\begin{array}{c}0.0 \pm 0.0 \mathrm{a} \\
7.5 \pm 2.5 \mathrm{bB} \\
49\end{array}$ & $\begin{array}{c}6.2 \pm 2.6 \mathrm{~A} \\
16.2 \pm 3.7 \mathrm{AB} \\
2.1 \mathrm{~A}\end{array}$ & $\begin{array}{l}8.7 \pm 2.2 \mathrm{~b} \\
25.0 \pm 3.7 \mathrm{a}\end{array}$ & $\begin{array}{c}0.0 \pm 0.0 \\
3.7 \pm 1.8 \mathrm{AB} \\
1.8\end{array}$ & $\begin{array}{l}8.7 \pm 2.2 \mathrm{aAB} \\
26.5 \pm 6.5 \mathrm{bB} \\
3.8\end{array}$ & $\begin{array}{c}11.2 \pm 1.2 \mathrm{a} \\
33.7 \pm 7.0 \mathrm{~b} \\
48\end{array}$ & $\begin{array}{l}2.5 \pm 2.5 \\
3.7 \pm 1.8 \mathrm{AB}\end{array}$ & $\begin{array}{l}.7 \pm 2.5 \mathrm{~A} \\
6.2 \pm 3.2 \mathrm{~A}\end{array}$ & $\begin{array}{l}18.7 \pm 6.3 \\
15.0 \pm 4.2\end{array}$ & $\begin{array}{l}0.0 \pm 0.0 \\
0.0 \pm 0.0 \mathrm{~A}\end{array}$ & $\begin{array}{l}1.2 \pm 1.2 \mathrm{~A} \\
2.5 \pm 1.6 \mathrm{~A} \\
0.4 \mathrm{~A}\end{array}$ & $\begin{array}{l}21.2 \pm 3.5 \\
22.5 \pm 3.1\end{array}$ \\
\hline $\begin{array}{l}\mathrm{F} \\
P\end{array}$ & $\begin{array}{l}2.9 \\
0.07\end{array}$ & $\begin{array}{l}3.5 \\
0.04\end{array}$ & $\begin{array}{l}2.4 \\
0.11\end{array}$ & $\begin{array}{l}4.7 \\
0.02\end{array}$ & $\begin{array}{l}5.6 \\
0.01\end{array}$ & $\begin{array}{l}3.2 \\
0.06\end{array}$ & $\begin{array}{l}4.9 \\
0.01\end{array}$ & $\begin{array}{l}2.1 \\
0.14\end{array}$ & $\begin{array}{l}12.0 \\
0.01\end{array}$ & $\begin{array}{l}1.8 \\
0.18\end{array}$ & $\begin{array}{c}3.8 \\
0.03\end{array}$ & $\begin{array}{c}4.8 \\
0.01\end{array}$ & $\begin{array}{l}0.7 \\
0.52\end{array}$ & $\begin{array}{c}0.2 \\
0.79\end{array}$ & $\begin{array}{l}0.1 \\
0.86\end{array}$ & & $\begin{array}{c}0.4 \\
0.66\end{array}$ & $\begin{array}{c}1.0 \\
0.38\end{array}$ \\
\hline
\end{tabular}

Within each exposure interval, post-exposure interval, and net formulation mortality, means followed by the same lowercase letter do not differ significantly according to the Tukey-Kramer

HSD test at $P<0.05$. Within each exposure interval, post-exposure interval, and net formulation, mortality means followed by the same uppercase letter do not differ significantly across treatments according to the Tukey-Kramer HSD test at $P<0.05$. Where no letters exist, no significant differences were noted. ANOVA parameters for 1 st day were: at 15 min, $\mathrm{F}=1.3$, $P=0.6,30 \mathrm{~min}, \mathrm{~F}=1.1, P=0.36,60 \mathrm{~min}, \mathrm{~F}=2.6, P=0.03$, for 7 th day were: at $15 \mathrm{~min}, \mathrm{~F}=1.2, P=0.30,30 \mathrm{~min}, \mathrm{~F}=5.1, P<0.01,60 \mathrm{~min}, \mathrm{~F}=6.1, P<0.01$, whereas for 10 th day were: at $15 \mathrm{~min}, \mathrm{~F}=2.4, P=0.05,30 \mathrm{~min}, \mathrm{~F}=1.9, P=0.12,60 \mathrm{~min}, \mathrm{~F}=2.2, P=0.07$, in all cases $d f=5,47$. In the case where "-" is indicated, F and $P$ values were not provided in the Table since no variances among the samples were recorded. 


\section{Discussion}

The results of our study indicated that even in the case of the longest exposure interval (180 min) no immediate mortality was achieved for either of the stored product species tested. However, for A. fabae, knockdown effect was vigorous and rapid, especially at longer intervals, as $\mathrm{KD}_{\mathrm{t} 50}$ was high after approximately one hour. In general, from the most to the least susceptible, the species/life stages tested here can be classified as $A$. fabae adults $>$ S. oryzae adults $>$ T. confusum larvae.

Particle size is highly associated with the insecticidal efficacy of inert dusts. Many authors have emphasized on the importance of the particle size, a significant physical property of dust formulations, underlining that formulations of smaller particles may enhance the insecticidal efficacy on a variety of stored-product beetles [34-39]. Korunić [40] found that the efficacy of DEs is promoted when particle size ranges between 1 and $30 \mu \mathrm{m}$. Similarly, Vayias et al. [38] indicated that DEs particles, sized up to $45 \mu \mathrm{m}$, resulted in higher mortality of stored product beetles, as compared with larger particles. However, Korunić [40] underlined the significance of the DEs origin, and concluded that even a high range between the size of particles (i.e., 0-192 $\mu \mathrm{m}$ ) could lead to similar insecticidal results, indicating the significance of the particle shape. In this context, Rumbos et al. [39] found that the insecticidal effect of zeolites on the control of stored-product pests was not highly associated with particle size.

Peng et al. [41] stated that the dispersity and stability of $\mathrm{SiO}_{2}$ nanoparticles are enhanced when added to liquid paraffin. In the present study, it was concluded that the susceptibility of $A$. fabae and $S$. oryzae was high, regardless of the addition of the primer or the size of silica nanoparticles, since no significant differences were recorded concerning the long-term effect. Notwithstanding, our results suggested that the use of paraffin on the net's surface contributes to the reduction of fabrics' shrinkage whereas it increases the rate of the particle deposition. Thus, the knockdown effect of $A$. fabae was increased when insects were exposed to ED5-P nets since in this case, the deposition of silica particles was the highest among all tested samples due to the addition of paraffin. In particular, it was shown that $99 \%$ of the adults were knocked down after six hours when exposed to the net coated with the ED5-P dust formulation, which consisted of the largest silica particles at the highest deposition rate.

Silica particles should not be considered as the only lethal factor in our study, as mortality can be also attributed to the presence of the net itself. As shown in the results corresponding to the control treatments, insects exposed to the $\mathrm{SiO}_{2}$-free nets were also affected by the presence of the net as opposed to the insects exposed to the dishes without net. Concerning the above, silica-treated nets could be applied on the vent openings of a greenhouse limiting the number of infestations due to greenhouse pests' invasions, which occurs mechanically, i.e., without the use of the dust. A similar approach has been investigated in the case of stored product insects, with similar results regarding the detrimental effect of the net to the insect bodies [17,20].

Although no immediate mortality was recorded for all the insect species tested, delayed mortality was high, reaching 100\% even in the shortest exposure time (15 min). Similarly, Kavallieratos et al. [42] observed a significant delayed mortality on $14 \mathrm{~d}$ for S. oryzae and the lesser grain borer, Rhyzopertha dominica (F.) (Coleoptrea: Bostrychidae) when exposed to a mixture of DE and abamectin. Our data show that, despite low initial effect, delayed mortality for the two beetle species was high, which clearly suggests that the exposed individuals were heavily affected by the presence of the dusts in their cuticles. As inert materials are slow-acting, it has been observed that mortality may take several days or even weeks to occur, even if the insects are in continuous contact with the dust particles $[43,44]$. Nevertheless, the current results suggest that even the shortest exposure to the dust particles tested here is irreversibly lethal, and recovery is less likely to appear. This is particularly important, as insects will eventually die after their removal from the treated substrate, a characteristic that is even more important in the case of aphids, if it is combined with the knockdown that appears rapidly after exposure.

To conclude, this study indicates that all of the nets tested here were effective for the control of aphids and less for beetles (including larval stage), despite variations in efficacy among treatments. Practically, the nets that are coated with inert materials can serve as a good alternatives to traditional pesticides in greenhouses but also in food and processing facilities, significantly moderating insect 
immigration. This technology can be adopted in a wide range of facilities, and also in food packaging, where the larval stage can penetrate with ease. At the same time, in a "real world" greenhouse scenario, immigration of aphids from the outside toward the plantation will force the insects to pass through the treated net, which is expected to be lethal, even if some aphids eventually pass successfully.

Author Contributions: Conceptualization, N.K., M.O., P.A. and C.G.A.; methodology, P.A., S.F. and E.L.; formal analysis, E.L., P.A. and S.F.; investigation, P.A., S.F., E.L., N.K. and C.G.A.; resources, N.K., C.G.A.; writing-original draft preparation, P.A., S.F., E.L., C.G.A. and N.K.; writing-review and editing, P.A., S.F., E.L., C.G.A. and N.K.; visualization, N.K., M.P. and M.O.; supervision, C.G.A. and N.K.; project administration, N.K., M.O. and M.P.; funding acquisition, N.K. and C.G.A. All authors have read and agreed to the published version of the manuscript.

Funding: This research has been co-financed by the European Union and Greek national funds through the National Action "Bilateral and Multilateral E\&T Cooperation Greece-Germany" (project code: T2DGE-0120). Furthermore, this research has been co-financed by the European Union and Greek national funds through the Operational Program Competitiveness, Entrepreneurship and Innovation, under the call RESEARCH-CREATE-INNOVATE (project code:T1EDK-01491).

Acknowledgments: This research has been co-financed by the European Union and Greek national funds through the National Action "Bilateral and Multilateral E\&T Cooperation Greece-Germany" (project code: T2DGE-0120). Furthermore, this research has been co-financed by the European Union and Greek national funds through the Operational Program Competitiveness, Entrepreneurship and Innovation, under the call RESEARCH-CREATE-INNOVATE (project code:T1EDK-01491).

Conflicts of Interest: The authors declare no conflict of interest.

\section{References}

1. Boyer, S.; Zhang, H.; Lempérière, G. A review of control methods and resistance mechanisms in stored-product insects. Bull. Entomol. Res. 2012, 102, 213-229. [CrossRef] [PubMed]

2. Athanassiou, C.-G.; Kavallieratos, N.-G.; Benelli, G.; Losic, D.; Usha Rani, P.; Desneux, N. Nanoparticles for pest control: Current status and future perspectives. J. Pest Sci. 2017, 91, 1-15. [CrossRef]

3. Awolola, T.-S.; Adeogun, A.; Olakiigbe, A.-K.; Oyeniyi, T.; Olukosi, Y.-A.; Okoh, H.; Arowolo, T.; Akila, J.; Oduola, A.; Amajoh, C.-N. Pyrethroids resistance intensity and resistance mechanisms in Anopheles gambiae from malaria vector surveillance sites in Nigeria. PLoS ONE 2018, 13, e0205230. [CrossRef]

4. Aktar, W.; Sengupta, D.; Chowdhury, A. Impact of pesticides use in agriculture: Their benefits and hazards. Interdiscip. Toxicol. 2009, 2, 1-12. [CrossRef] [PubMed]

5. Mukherjee, A.; Knoch, S.; Chouinard, G.; Tavares, J.-R.; Dumont, M.-J. Use of bio-based polymers in agricultural exclusion nets: A perspective. Biosyst. Eng. 2019, 180, 121-145. [CrossRef]

6. Kittas, C.; Katsoulas, N.; Bartzanas, T.; Mermier, M.; Boulard, T. The impact of insect screens and ventilation openings on the greenhouse microclimate. Trans. ASABE 2008, 51, 2151-2165. [CrossRef]

7. Kitta, E.; Baille, A.-D.; Katsoulas, N.; Rigakis, N.; González-Real, M.-M. Effects of cover optical properties on screenhouse radiative environment and sweet pepper productivity. Biosyst. Eng. 2014, 122, 115-126. [CrossRef]

8. Teitel, M. The effect of screened openings on greenhouse microclimate. Agric. For. Meteorol. 2007, 143, 159-175. [CrossRef]

9. Dáder, B.; Legarrea, S.; Moreno, A.; Ambros, C.-M.; Fereres, A.; Skovmand, O.; Bosselmann, R.; Viñuela, E. Insecticide-treated nets as a new approach to control vegetable pests in protected crops. Acta Hortic. 2014, 1015, 103-112. [CrossRef]

10. Rigakis, N.; Katsoulas, N.; Teitel, M.; Bartzanas, T.; Kittas, C. A simple model for ventilation rate determination in screenhouses. Energy Build. 2015, 87, 293-301. [CrossRef]

11. Bell, M.-L.; Baker, J.-R. Comparison of greenhouse screening materials for excluding whitefly (Homoptera: Aleyrodidae) and thrips (Thysanoptera: Thripidae). J. Econ. Entomol. 2000, 93, 800-804. [CrossRef] [PubMed]

12. Parra, J.-P.; Baeza, E.; Montero, J.-I.; Bailey, B.-J. Natural ventilation of parral greenhouses. Biosyst. Eng. 2004, 87, 355-366. [CrossRef]

13. Fatnassi, H.; Boulard, T.; Demrati, H.; Bouirden, L.; Sappe, G. Ventilation performance of a large Canarian-type greenhouse equipped with insect-proof nets. Biosyst. Eng. 2002, 82, 97-105. [CrossRef]

14. Katsoulas, N.; Bartzanas, T.; Boulard, T.; Mermier, M.; Kittas, C. Effect of vent openings and insect screens on greenhouse ventilation. Biosyst. Eng. 2006, 93, 427-436. [CrossRef] 
15. Baeza, E.-J.; Pérez-Parra, J.-J.; Montero, J.-I.; Bailey, B.-J.; López, J.-C.; Gázquez, J.-C. Analysis of the role of sidewall vents on buoyancy-driven natural ventilation in parral-type greenhouses with and without insect screens using computational fluid dynamics. Biosyst. Eng. 2009, 104, 86-96. [CrossRef]

16. Chouinard, G.; Veilleux, J.; Pelletier, F.; Larose, M.; Philion, V.; Cormier, D. Impact of exclusion netting row covers on arthropod presence and crop damage to 'Honeycrisp' apple trees in North America: A five-year study. Crop Prot. 2017, 98, 248-254. [CrossRef]

17. Rumbos, C.-I.; Sakka, M.; Schaffert, S.; Sterz, T.; Austin, J.-W.; Bozoglou, C.; Klitsinaris, P.; Athanassiou, C.-G. Evaluation of Carifend ${ }^{\circledR}$, an alpha-cypermethrin-coated polyester net, for the control of Lasioderma serricorne and Ephestia elutella in stored tobacco. J. Pest Sci. 2018, 91, 751-759. [CrossRef]

18. Dáder, B.; Legarrea, S.; Moreno, A.; Plaza, M.; Carmo-Sousa, M.; Amor, F.; Viñuela, E.; Fereres, A. Control of insect vectors and plant viruses in protected crops by novel pyrethroid-treated nets. Pest Manag. Sci. 2014, 71, 1397-1406. [CrossRef] [PubMed]

19. Arthurs, S.-P.; Krauter, P.-C.; Gilder, K.; Heinz, K.-M. Evaluation of deltamethrin-impregnated nets as a protective barrier against Western flower thrips, Frankliniella occidentalis (Thysanoptera: Thripidae) under laboratory and greenhouse conditions. Crop Prot. 2018, 112, 227-231. [CrossRef]

20. Paloukas, Y.-Z.; Agrafioti, P.; Rumbos, C.-I.; Schaffert, S.; Sterz, T.; Bozoglou, C.; Klitsinaris, P.; Austin, J.-W.; Athanassiou, C.-G. Evaluation of Carifend ${ }^{\circledR}$ for the control of stored-product beetles. J. Stored Prod. Res. 2020, 85. [CrossRef]

21. Epstein, E. The anomaly of silicon in plant biology. Proc. Natl. Acad. Sci. USA 1994, 91, 11-17. [CrossRef] [PubMed]

22. Rastogi, A.; Tripathi, D.-K.; Yadav, S.; Chauhan, D.-K.; Živčák, M.; Ghorbanpour, M.; El-Sheery, N.-I.; Brestic, M. Application of silicon nanoparticles in agriculture. 3 Biotech 2019, 9, 90. [CrossRef] [PubMed]

23. Debnath, N.; Mitra, S.; Das, S.; Goswami, A. Synthesis of surface functionalized silica nanoparticles and their use as entomotoxic nanocides. Powder Technol. 2012, 221, 252-256. [CrossRef]

24. Barik, T.-K.; Sahu, B.; Swain, V. Nanosilica-From medicine to pest control. Parasitol. Res. 2008, 103, $253-258$. [CrossRef]

25. Benelli, G. Mode of action of nanoparticles against insects. Environ. Sci. Pollut. Res. 2018, 25, 12329-12341. [CrossRef]

26. Vayias, B.-J.; Athanassiou, C.-G. Factors affecting the insecticidal efficacy of the diatomaceous earth formulation SilicoSec against adults and larvae of the confused flour beetle, Tribolium confusum DuVal (Coleoptera: Tenebrionidae). Crop Prot. 2004, 23, 565-573. [CrossRef]

27. Ng, J.C.-K.; Perry, K.-L. Transmission of plant viruses by aphid vectors. Mol. Plant Pathol. 2004, 5, 505-511. [CrossRef]

28. Singh, B.; Singh, V. Laboratory and field studies demonstrating the insecticidal potential of diatomaceous earth against wheat aphids in rice-wheat cropping system of Punjab (India). Cereal Res. Commun. 2016, 44, 435-443. [CrossRef]

29. Shoaib, A.; Elabasy, A.; Waqas, M.; Lin, L.; Cheng, X.; Zhang, Q.; Shi, Z.H. Entomotoxic effect of silicon dioxide nanoparticles on Plutella xylostella (L.) (Lepidoptera: Plutellidae) under laboratory conditions. Toxicol. Environ. Chem. 2018, 100, 80-91. [CrossRef]

30. Debnath, N.; Das, S.; Seth, D.; Chandra, R.; Bhattacharya, S.-C.; Goswami, A. Entomotoxic effect of silica nanoparticles against Sitophilus oryzae (L.). J. Pest Sci. 2011, 84, 99-105. [CrossRef]

31. Eroglu, N.; Emekci, M.; Athanassiou, C.-G. Applications of natural zeolites on agriculture and food production. J. Sci. Food Agric. 2017, 97, 3487-3499. [CrossRef] [PubMed]

32. Papanikolaou, N.-E.; Martinou, A.-F.; Kontodimas, D.-C.; Matsinos, Y.-G.; Milonas, P.-G. Functional responses of immature stages of Propylea quatuordecimpunctata (Coleoptera: Coccinellidae) to Aphis fabae (Hemiptera: Aphididae). Eur. J. Entomol. 2011, 108, 391-395. [CrossRef]

33. Faliagka, S.; Agrafioti, P.; Lampiri, E.; Katsoulas, N.; Athanassiou, C.G. Assessment of different inert dust formulations for the control of Sitophilus oryzae, Tribolium confusum and Aphis fabae. Crop Prot. 2020, 137, 105312. [CrossRef]

34. Kavallieratos, N.-G.; Athanassiou, C.-G.; Vayias, B.-J.; Kotzamanidis, S.; Synodis, S.-D. Efficacy and adherence ratio of diatomaceous earth and spinosad in three wheat varieties against three stored-prosuct insect pests. J. Stored Prod. Res. 2010, 46, 73-80. [CrossRef] 
35. Kavallieratos, N.-G.; Athanassiou, C.-G.; Mpassoukou, A.-E.; Mpakou, F.-D.; Tomanovic, Z.; Manessioti, T.-B.; Papadopoulou, S.-C. Bioassays with diatomaceous earth formulations: Effect of species co-occurrenece, size of vials and application technique. J. Stored Prod. Res. 2012, 42, 170-179. [CrossRef]

36. Athanassiou, C.-G.; Kavallieratos, N.-G.; Andris, N.-S. Insecticide effect of three diatomaceous earth formulations against adults of Sitophlus oryzae (Coleoptera: Curcilionidae) and Tribolium confusum (Coleoptera: Tenebrionidae) on oat, rye and triticale. J. Econ. Entomol. 2004, 97, 2160-2167. [CrossRef]

37. Athanassiou, C.-G.; Vassilakos, N.-T.; Dutton, A.-C.; Jeesop, N.; Sherwood, D.; Pease, G.; Brglez, A.; Storm, C.; Trdan, S. Combining electrostatic powder with an insecticide: Effect on stored prosuct beetles and on the commodity. Pest Manag. Sci. 2016, 72, 2208-2217. [CrossRef]

38. Vayias, B.-J.; Athanassiou, C.-G.; Korunic, Z.; Rozman, V. Evaluation of natural diatomaceous earth deposits from south-eastern Europe for stored-grain protection: The effect of particle size. Pest Manag. Sci. 2009, 65, 1118-1123. [CrossRef]

39. Rumbos, C.-I.; Sakka, M.; Berillis, P.; Athanassiou, C.-G. Insecticidal potential of zeolite formulations against three stored-grain insects, particle size effect, adherence to kernels and influence on test weight of grains. J. Stored Prod. Res. 2016, 68, 93-101. [CrossRef]

40. Korunić, Z. Rapid assessment of the insecticidal value of diatomaceous earths without conducting bioassays. J. Stored Prod. Res. 1997, 33, 219-229. [CrossRef]

41. Peng, D.-X.; Kang, Y.; Hwang, R.-M.; Shyr, S.-S.; Chang, Y.-P. Tribological properties of diamond and $\mathrm{SiO}_{2}$ nanoparticles added in paraffin. Tribol. Int. 2009, 42, 911-917. [CrossRef]

42. Kavallieratos, N.-G.; Athanassiou, C.-G.; Korunic, Z.; Mikeli, N.-H. Evaluations of three novel diatomaceous earths against three stored-grain beetle species on wheat and maize. Crop Prot. 2015, 75, 132-138. [CrossRef]

43. Subramanyam, B.; Roesli, R. Inert dusts. In Alternatives to Pesticides in Stored-Product IPM; Springer: Boston, MA, USA, 2000; pp. 321-380.

44. Athanassiou, C.-G.; Vayias, B.-J.; Dimizas, C.-B.; Kavallieratos, N.-G.; Papagregoriou, A.-S.; Buchelos, C.-T. Insecticidal efficacy of diatomaceous earth against Sitophilus oryzae (L.) (Coleoptera: Curculionidae) and Tribolium confusum du Val (Coleoptera: Tenebrionidae) on stored wheat: Influence of dose rate, temperature and exposure interval. J. Stored Prod. Res. 2005, 41, 47-55. [CrossRef]

(C) 2020 by the authors. Licensee MDPI, Basel, Switzerland. This article is an open access article distributed under the terms and conditions of the Creative Commons Attribution (CC BY) license (http://creativecommons.org/licenses/by/4.0/). 